\title{
Explorer Travellers and Adventure Tourism
}

By Jennifer Laing and Warwick Frost. Channel View Publications $<$ www.channelviewpublications. com>, 2014 vii + 263. (figures, bibliography, index), \$Au 40.17, Pbk. ISBN: 978-1-84541-457-3.

From an academic perspective, this slim volume is rather a chimaera. It is published by Channel View, one of a series on Tourism and Cultural Change. But it is not a typical research text. Instead, the authors interweave their own narratives, ancient myths, published literature, and occasional quotations from interviewees to construct a story about a particular subset of modern day tourists as reflecting historical social ideals of exploration. The result is readable and reasonably plausible. Because there is no clearly stated research question, method, data, or analysis, however, the reader cannot tell how accurate or reliable the conclusions may be.

Their case seems to be that there are heroic individuals, whom these authors call explorer travellers, who make their way through foreign lands without the help of guides or tour companies, paving the way for commercial adventure tourism. The difficulty is that this confounds two testable but distinct propositions. The first is that some individuals in the past carried out exploits which required skill and bravery, and this also applies to some individuals and exploits in the present, including outdoor activities and journeys. To be useful analytically, however, this needs a definition of heroism in a travel context, which is not provided.

The second proposition is that destinations, journeys, and activities are explored first by independent private groups, and that this paves the way for later commercial adventure tourism. This is a well-established suggestion (Buckley, 2006, 2010). River explorations in China, for example (Buckley, 2006), led to commercial rafting tours; but not directly (Buckley, McDonald, Duan, Sun, \& Chen, 2014). In addition, even though one of the early descents was indeed written up in the Explorers Journal (Van Beek, 1998), such precursors to commercial adventure tours are not necessarily heroic.

These difficulties may be illustrated for several of the cases cited as explorer travellers. Backpacking, for example, is now a highly organised subsector with its own commercial 
transport, accommodation, activity providers, and communications channels. Even in the early 1970s, when the terms backpacker and hippie trail were yet to be invented and Lonely Planet was still a gleam in its founder's eyes, low-budget independent travel in Africa and Asia was hardly heroic.

First ascents, descents, and traverses in various forms of outdoor recreation are also cited. While some of these are indeed heroic exploits, only some involve independent travel. Individuals who haul a sledge across Antarctica, or set out to ski solo to the North Pole, do indeed battle heroic obstacles. Many outdoor firsts, however, involve advance scouting, support crews, commercial sponsorship, satellite communications, television camera teams, emergency evacuation arrangements, and event organisers. The protagonists may be brave, but not independent.

As an illustration, consider crossings of Australia's Simpson Desert, $200 \mathrm{~km}$ of dry dunefields (Buckley, 2006). Consider: scientific expedition by camel in the 1930s. A solo geologist in car in the 1950s. A bulldozer in the 1960s for oil exploration. Off-track solo 4WD traverses for Ph.D. research in the 1970s. A solo foot traverse dragging a water cart in the 1980s. Commercial tagalong 4WD tracks along cleared sand tracks in the 1990s. Which of these would qualify as explorer travellers?

The third example is space tourism, and the book includes an entire chapter on tourism to Mars. Given that the proposed Virgin Galactic space-hop tours have recently been postponed once more, commercial tourism to Mars seems unlikely in the immediately foreseeable future. In addition, even if it were feasible, space tourism will surely be a completely choreographed experience, diametrically opposed to the concept of independent exploration.

Many good ideas, especially in the humanities, have first been published as books. Many scientists and social scientists have written books in story-telling or journalistic format for a broad audience, with inconspicuous but extensive footnotes for academic readers or critics. This volume has elements of both models. Its thesis, however, is not defined with sufficient clarity, nor argued with sufficient rigour, to be convincing. I like the idea of explorer travellers, but I am not persuaded that Homer's Odyssey is an appropriate analytical analogue for modern backpackers, polar explorers, or space tourists. 


\section{References}

Buckley, R. (2006). Adventure tourism. Wallingford: CAB International.

Buckley, R. (2010). Adventure tourism management. Oxford: Elsevier.

Buckley, R., McDonald, K., Duan, L., Sun, L., \& Chen, L.-X. (2014). Chinese model for mass adventure tourism. Tourism management, 44, 5-13.

Van Beek, S. (1998). The power of one. Explorers Journal, Summer, 1998, 22-29.

Ralf C. Buckley

International Chair in Ecotourism Research,

Griffith University, Gold Coast, Qld, 4222, Australia

r.buckley@griffith.edu.au 